\title{
카로티노이드를 함유한 노랑찰옥수수 ‘황미찰’
}

이진석 ${ }^{1 *} \cdot$ 손범영 ${ }^{1}$ - 신성휴 ${ }^{2} \cdot$ 김정태 $^{1} \cdot$ 배환희 $^{1}$ - 백성범 ${ }^{1}$ - 정태욱 ${ }^{1}$ - 김성국 ${ }^{1}$ - 권영업 ${ }^{1}$

${ }^{1}$ 농촌진흥청 국립식량과학원, ${ }^{2}$ 농촌진흥청

\section{'Hwangmichal', a Yellow Waxy Corn F1 Hybrid with High Carotenoid Content}

\author{
Jinseok Lee ${ }^{1 *}$, Beom-Young Son ${ }^{1}$, Seong-Hyu Shin ${ }^{2}$, Jung-Tae Kim ${ }^{1}$, Hwan-Hee Bae ${ }^{1}$, Seong-Bum Baek ${ }^{1}$, \\ Tae-Wook Jung ${ }^{1}$, Sung-Kook Kim ${ }^{1}$, and Young-Up Kwon ${ }^{1}$ \\ ${ }^{1}$ National Institute of Crop Science, RDA, Suwon, 16429, Republic of Korea \\ ${ }^{2}$ Rural Development Administration, Jeonju, 54875, Republic of Korea
}

\begin{abstract}
Hwangmichal, a yellow waxy corn hybrid, is a single cross hybrid developed in 2014. This hybrid was created by crossing the seed parent KY30 and pollen parent KY9. Hwangmichal has yellow kernels with a conico-cylindrical ear shape. The days to silking of Hwangmichal were similar to that of Ilmichal, a check hybrid. The ear height ratio of Hwangmichal was 50\%, which was lower than that of Ilmichal, and its number of tillers was less than that of Ilmichal. The ear size of Hwangmichal was smaller than that of Ilmichal and the kernel set ratio was $89 \%$. Its sensory evaluation was better than that of Ilmichal. The carotenoid content of Hwangmichal was $32.2 \mu \mathrm{g} / \mathrm{g}$, which was much higher than that of Ilmichal. Lodging resistance of Hwangmichal was better than that of Ilmichal. Although the number of fresh ears of Hwangmichal was more than that of Ilmichal, the weight of fresh ears was lower than that of Ilmichal. The flowering period of its parent lines was well matched and seed production was 3:1 at a planting density of parent lines of more than 2:1. It is adaptable to the whole country except for Jeju-do. The plant variety protection right of Hwangmichal was registered in June 2017, and its grant number is 6728 .
\end{abstract}

Keywords Carotenoid, Waxy, Corn, Hybrid, Hwangmichal

Received on September 7, 2018. Revised on October 8, 2018. Accepted on October 12, 2018.

* Corresponding Author (E-mail: z9813139@korea.kr, Tel: +82-31-695-4043, Fax: +82-31-695-4029)

\section{서 언}

옥수수는 볏과(Poaceae)에 속하는 일년생 작물로 세계3대 작물의 하나이며 전 세계적으로 매년 10 억톤 이상 생산되어 이용되고 있다(FAOSTAT 2016). 옥수수는 알곡의 특성에 따라 크게 일반옥수수와 특수옥수수로 나눌 수 있으며 일반옥수수는 주로 사료용, 가공용 등으로 이용이 되고 있다. 우리나라에서 주로 간식용으로 이용하는 찰옥수수는 배유 돌연변이에 의해 전분 특성이 변화된 특수옥수수이며 이외에도 단옥수수, 초당옥 수수 등이 이에 속한다(Hallauer 2001).

1989년 우리나라에서 찰옥수수 중에서는 최초로 단교잡종 찰옥1호가 개발되었고 이후 우수한 품질의 찰옥수수들이 지속적 으로 개발되고 있으며 재배면적 또한 1989년 약 8천ha에서 최근 에는 15천 ha로 지속적으로 증가하고 있다(RDA 2013).

2000년 이후 찰옥수수 품질에 대한 관심이 높아지면서 찰옥1
호보다 품질이 우수한 미백찰(Park et al. 2002a), 신찰옥(Cha et al. 2004a), 찰옥3호(Cha et al. 2004b), 찰옥4호(Jung et al. 2006a), 일미찰(Jung et al. 2006b), 미백2호(Park et al. 2007a), 장수찰(Seo et al. 2018) 등 고품질의 흰찰옥수수 품종이 개발되 었고 미흑찰(Park et al. 2007b), 흑진주찰(Jung et al. 2009), 청춘찰(Park et al. 2016) 등 안토시아닌을 함유하여 항산화 등 기능성이 향상된 품종들도 지속적으로 개발되어 보급되고 있다. 최근에는 대학찰 골드1호(Lee et al. 2009) 등 카로티노이드를 함유한 찰옥수수 품종도 개발되기 시작하였지만 아직 상용화되 지는 못하였다. 하지만 카로티노이드를 함유한 노랑찰옥수수는 기존의 찰옥수수와 이삭색, 기능성 등에 차별성을 가지고 있어 시장가치가 충분할 것으로 기대된다.

카로티노이드는 황색에서 적색까지 다양한 색깔을 나타내는 지용성 생리활성물질로 엽록체에서 생성되어 광합성과정에 중 요한 역할을 하며 빛과 산소에 의한 손상을 억제하는 기능을 
한다(Ong \& Tee 1992, Pfander 1992, Tanaka et al. 2008). 카로티노이드는 옥수수 내에서 lutein, zeaxanthin, $\alpha$-carotene, $\beta$-carotene 등의 형태로 존재하며 비타민A의 생합성에 관여하 고 눈의 보호, 면역력 향상, 항산화, 항암 등 다양한 기능성을 나타낸다(Cazzonelli 2011, Eldahshan \& Singab 2013).

농촌진흥청 국립식량과학원에서는 간식용 풋찰옥수수의 기 능성 강화를 통한 국민건강증진을 위하여 카로티노이드를 함유 한 ‘황미찰’을 육성하였으며 그 육성경위와 주요특성을 보고하 고자 한다.

\section{재료 및 방법}

지역적응시험은 2012년부터 2014년까지 3년간 수원, 홍천, 청원, 대구, 진주 등 5 지역에서 수행하였다. 시비량은 $\mathrm{N}-\mathrm{P}_{2} \mathrm{O}_{5}-$ $\mathrm{K}_{2} 0=15-3-6 \mathrm{~kg} / 10 \mathrm{a}$ 으로 질소의 반량은 기비로 나머지 반량은 7 8엽기에 추비로 주었다. 시험구는 난괴법 4반복으로 임의배치 하였으며, 재식거리는 $60 \times 25 \mathrm{~cm}(6,600$ 주/10a)로 각 시험구는 열길이 $4 \mathrm{~m}, 4$ 열로 파종하였다. 파종은 4월 중순 하순에 수원 등 5 개 지역에서 각각 하였으며, 2립씩 파종하여 3 4엽기에 1 주에 1 개체만 남기고 솎아 주었다. 깨씨무늬병(Bipolaris maydis), 그을음무늬병(Exserohilum turcicum), 조명나방(Ostrina furnacalis) 등은 자연발생조건에서 조사하였으며 농업적 특성 및 수량성은 농촌진흥청 농업과학기술 연구조사분석기준에 따 라 조사하였다(RDA 2012).

아밀로펙틴 함량은 AMYLOSE/AMYLOPECTIN kit (Megazyme, Cat. $\mathrm{K}=\mathrm{AMYL})$ 을 이용하여 아밀로스 함량을 분석한 후 다음의 식을 이용하여 구하였다.

아밀로펙틴 함량(\%)=100-아밀로스 함량(\%)

과피두께는 풋옥수수 이삭의 포엽을 제거한 후 낱알을 채취하 여 과피두께, 백립중, 낱알의 길이와 폭, 경도 등 품질분석에
이용하였다. 과피두께는 낱알의 끝모자부와 상단부를 면도칼을 이용하여 제거하고 낱알의 등부위를 세로로 잘라 과피를 벗겨내 어 세척한 후 24시간 음건하였으며 건조된 과피를 디지털 두께 게이지(Mitutoyo, Japan)를 이용하여 측정하였다.

백립중은 낱알 100 립의 중량을 측정하였으며 낱알의 길이와 폭은 버니어 캘리퍼스(Mitutoyo, Japan)를 이용하여 측정하였다. 경도는 옥수수 낱알을 Texture analyzer (TAX, England)를 이용 하여 점착성, 껌성, 응집성, 씹힘성을 측정하였으며 식미관능평 가는 표준품종인 일미찰과 비교하여 외관, 찰기, 씹힘성, 전체기 호도를 9 점 척도 11 : 아주 나쁨, $3:$ 나쁨, $5:$ 보통, $7:$ 좋음, 9 : 아주 좋음)로 하여 평가하였다.

채종시험은 2014년 영월지역에서 수행하였고 6 월 10 일에 재 식거리는 $60 \times 25 \mathrm{~cm}(6,600$ 주/10a)로 2립씩 파종하여 3 4엽기 에 1 주에 1 개체만 남기고 솎아 주었으며 식용옥수수 표준재배방 법으로 재배하였다. 시험구는 모·부본 재식비율 2:1과 3:1로 각 처리마다 3 반복으로 배치하였고, 모본의 제웅은 출웅할 때 수작업으로 수행하였다. 생육특성, 개화기, 채종량은 농촌진흥청 농업과학기술 연구조사분석기준에 따라 실시하였다(RDA 2012). 자료의 통계처리는 SAS 9.2 (SAS Institute inc.) 프로그램을 사용하여 Student's T-test로 수행하였다.

\section{결과 및 고찰}

\section{육성경위}

황미찰(수원찰69호)은 카로티노이드 함량이 높은 자식계통 $\mathrm{KY} 30$ 을 종자친(모본)으로 하고 KY30과 개화기가 유사하고 카로티노이드 함량이 높은 자식계통 KY9를 화분친(부본)으로 하여 2009년에 교잡된 노랑찰옥수수 단교잡종이다. 황미찰은 2010년 생산력검정시험을 거쳐, 2012년부터 2014년까지 3년 동안 수원 등 전국 5 개 지역에서 지역적응시험을 실시하였으며 2014년 농촌진흥청 농작물 직무육성품종 심의회에서 그 우수성 이 인정되어 직무육성 신품종으로 선정되었으며 품종명을 ‘황미

\begin{tabular}{|c|c|c|c|c|c|c|}
\hline \multirow{2}{*}{ Year } & 우 & 1996 & 1997 2005 & 2006 & \multirow{2}{*}{2009} & \multirow{2}{*}{ 2012 2014 } \\
\hline & $\hat{\delta}$ & 1999 & 1999 2000 & 2001 & & \\
\hline Generation & & & $\mathrm{S}_{0} \sim \mathrm{S}_{8}$ & Inbred & \multicolumn{2}{|c|}{ Multiplication \& cross } \\
\hline Female (우) & $\mathrm{KV}$ & $83-1$ & YS97039-1-1-2-1-1-1-2-YWK0506 & KY30 & \multirow{2}{*}{$\begin{array}{c}\text { KY30/KY9 } \\
(2010)\end{array}$} & \multirow{2}{*}{$\begin{array}{l}\text { Hwangmichal } \\
\text { (Suwonchal 69) }\end{array}$} \\
\hline Male $(\hat{\delta})$ & $\mathrm{BN}$ & 005) & $9967-1$ & KY9 & & \\
\hline Remark & \multicolumn{3}{|c|}{ Selection of line } & Cross & Yield trial & Regional yield trial (RYT) \\
\hline
\end{tabular}

Fig. 1. Breeding procedure of Hwangmichal. 
찰’로 명명하였다(Fig. 1).

\section{주요 생육 및 품질관련 특성}

황미찰은 립색이 황색으로 대학찰 골드1호(Lee et al. 2009)와 유사하지만 일미찰(Jung et al. 2006b), 흑진주찰(Jung et al. 2009) 등 기존의 상용화되어 있는 백색 혹은 검정색의 찰옥수수와는 뚜렷이 구별된다. 황미찰은 찰옥수수 단교잡종으로, 이삭은 중간 형이며 출사일수는 71일로 표준품종(일미찰)과 유사하다. 황미찰 의 간장은 $211 \mathrm{~cm}$ 로 일미찰과 유의한 차이는 없었으나 착수고율 은 $50 \%$ 로 일미찰보다 작고 안정적이었다(Fig. 2, Table 1). 황미찰
의 분지수는 일미찰보다 적어 옥수수 포장 내 통기성과 제초, 추비살포 등 재배관리에 유리할 것으로 생각되었다. 옥수수의 분지가 과번무하면 포장 통기성에 불리하게 작용하고 포장 내 습한 환경을 조성하여 세균성 잎마름병(bacterial leaf blight) 등 병 발생의 원인이 될 수 있다(Drobotă et al. 2011). 황미찰의 이삭의 길이와 폭은 일미찰보다 유의하게 작아 전체적인 이삭 크기가 작았으며 착립장률 역시 일미찰보다 낮았다(Table 1). 황미찰의 아밀로펙틴 함량은 $90.9 \%$ 로 일미찰과 유의한 차이는 없었고 백립중, 립장, 립폭 등 알곡의 특성에서도 일미찰과 유의한 차이는 나타내지 않았다(Table 2). 찰옥수수의 특성을 나타내는

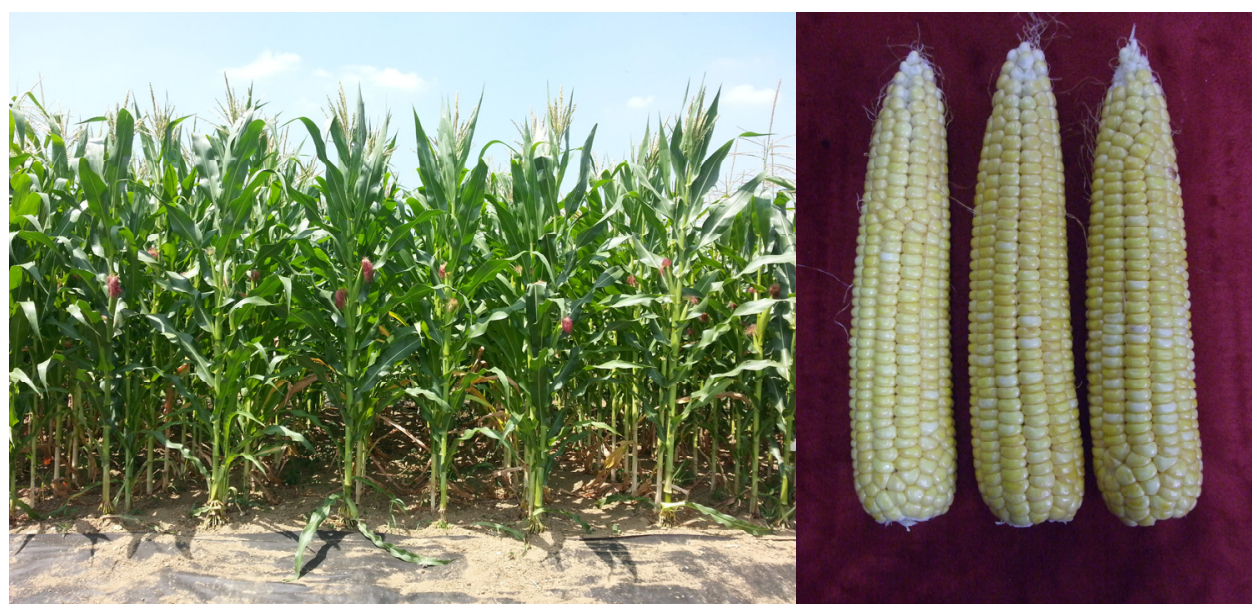

Fig. 2. Plants and ears of Hwangmichal (left: plants, right: ears).

Table 1. Agronomic characteristics of Hwangmichal in regional yield test (2012 2014).

\begin{tabular}{lccccccc}
\hline Hybrid & $\begin{array}{c}\text { Days to silking } \\
(\text { days })\end{array}$ & $\begin{array}{c}\text { Stem length } \\
(\mathrm{cm})\end{array}$ & $\begin{array}{c}\text { Ear height ratio } \\
(\%)\end{array}$ & $\begin{array}{c}\text { Number of } \\
\text { tillers } \\
\text { (tillers/plant) }\end{array}$ & $\begin{array}{c}\text { Length } \\
(\mathrm{cm})\end{array}$ & $\begin{array}{c}\text { Width } \\
(\mathrm{cm})\end{array}$ & $\begin{array}{c}\text { Kernel set ratio } \\
(\%)\end{array}$ \\
\hline Hwangmichal & 71 & 211 & 50 & 0.1 & 18.4 & 4.3 & 89 \\
Ilmichal & 71 & 218 & 54 & 0.9 & 19.4 & 4.5 & 95 \\
\hline $\mathrm{ts}^{\mathrm{z}}$ & $-0.31^{\mathrm{ns}}$ & $-1.49^{\mathrm{ns}}$ & $-2.63^{* *}$ & $-9.19^{* *}$ & $-5.14^{* *}$ & $-0.36^{* *}$ & $-6.51^{* *}$ \\
\hline
\end{tabular}

${ }^{\mathrm{z}}$ Student's T-test at the 0.05 probability level $\left({ }^{* *} p<0.01,{ }^{*} p<0.05 ;{ }^{\text {ns }} p \geq 0.05\right)$

Table 2. Kernel quality and sensory evaluation of Hwangmichal in regional yield test (2012 2014).

\begin{tabular}{|c|c|c|c|c|c|c|c|}
\hline \multirow[b]{2}{*}{ Hybrid } & \multirow{2}{*}{$\begin{array}{l}\text { Amylopectin } \\
\text { content }(\%)\end{array}$} & \multirow{2}{*}{$\begin{array}{c}\text { Pericarp } \\
\text { thickness }(\mu \mathrm{m})\end{array}$} & \multicolumn{3}{|c|}{ Kernel characteristics } & \multirow{2}{*}{$\begin{array}{c}\text { Carotenoid } \\
\text { content } \\
(\mu \mathrm{g} / \mathrm{g})\end{array}$} & \multirow{2}{*}{$\begin{array}{c}\text { Sensory } \\
\text { evaluation } \\
(1 \sim 9)^{\mathrm{z}}\end{array}$} \\
\hline & & & $\begin{array}{l}\text { 100-kernel } \\
\text { weight }(\mathrm{g})\end{array}$ & $\begin{array}{l}\text { Length } \\
(\mathrm{mm})\end{array}$ & $\begin{array}{c}\text { Width } \\
(\mathrm{mm})\end{array}$ & & \\
\hline Hwangmichal & 90.9 & 45 & 26.8 & 7.23 & 8.38 & 32.2 & 6.1 \\
\hline Ilmichal & 91.2 & 50 & 30.3 & 7.99 & 8.83 & 5.1 & 5.0 \\
\hline $\mathrm{ts}^{\mathrm{y}}$ & $-0.34^{\mathrm{ns}}$ & $-1.99^{\mathrm{ns}}$ & $-0.68^{\mathrm{ns}}$ & $-1.85^{\mathrm{ns}}$ & $-0.42^{\mathrm{ns}}$ & - & $3.66^{*}$ \\
\hline
\end{tabular}

${ }^{\mathrm{z}}$ Sensory evaluation (1: poor, 9: excellent)

${ }^{\mathrm{y}}$ Student's T-test at the 0.05 probability level $\left({ }^{* *} p<0.01,{ }^{*} p<0.05 ;{ }^{\mathrm{ns}} p \geq 0.05\right)$ 
$w x$ 유전자에는 $w x 1$-a와 $w x 1$-c가 보고되고 있으며 $w x 1-\mathrm{a}$ 가 배유 전분의 $100 \%$ 를 아밀로펙틴으로 발현하는 반면 $w x 1$-c는 배유 전분의 약 $95 \%$ 를 아밀로펙틴으로 발현하며 나머지 $5 \%$ 는 아밀로 스로 발현한다. 하지만 전분의 구성을 분석할 때 짧은 사슬의 아밀로스는 아밀로펙틴으로, 긴 사슬의 아밀로펙틴은 아밀로스로 잘못 분석되기 쉬우므로 정확한 전분의 구성성분 분석은 어려울 것으로 생각된다(Hallauer 2001). 황미찰의 과피두께는 $45 \mu \mathrm{m}$ 로 일미찰과 유의한 차이는 나타내지 않았으나 $50 \mu \mathrm{m}$ 이하로 얇아 질김성이 낮을 것으로 판단되었고 황미찰의 전체적인 기호도가 6.1로 일미찰보다 높아 이삭의 외관, 맛 등 시장가치가 좋을 것으로 생각되었다(Lee et al. 1993). 황미찰의 카로티노이드 함량은 32.2 $\mu \mathrm{g} / \mathrm{g}$ 으로 일미찰보다 상당히 높아 기능성면에서 우수할 것으로 판단되었다. 황미찰이 함유하고 있는 카로티노이드는 눈과 피부 의 건강과 면역력향상에 도움을 주는 생리활성 물질로 기존의 상용화되어 있는 찰옥수수들과는 차별화되는 특성이며 새로운 형질의 찰옥수수 보급을 통해 국민건강증진 및 농가소득향상에 기여할 수 있을 것으로 기대하고 있다(Table 2).

\section{병충해 및 내재해성}

2012년부터 2014년까지 3년간 자연발생조건에서 황미찰의 병해충 저항성을 검정한 결과, 깨씨무늬병(Bipolaris maydis)은 발병등급 2, 그을음무늬병(Exserohilum turcicum)은 발병등급
1 로 일미찰과 유사하게 병 저항성이 강한 것으로 조사되었고 조명나방 발생등급은 4 로 일미찰과 동일하게 중도저항성을 나타 내었다(Table 3). 내도복성은 황미찰이 일미찰보다 강한 것으로 조사되어 재배안정성은 더 높은 것으로 생각되었다(Table 3).

\section{수량성}

2012년부터 2014년까지 3년간 수원 등 5개 지역에서 풋찰옥 수수 수확시기에 이삭수와 이삭중 등 수량성을 조사한 결과, 황미찰의 $10 \mathrm{a}$ 풋이삭수 평균은 6,319 개/10a로 일미찰보다 유의 하게 많았고 지역적으로 홍천이 가장 적고 진주에서 가장 많았다. 지역별 일미찰과 비교시 수원에서 $12 \%$, 대구에서 $7 \%$, 청원에서 $4 \%$ 증수하였으나 그 외 홍천과 진주에서는 일미찰보다 낮았다 (Table 4). 황미찰의 $10 \mathrm{a}$ 당 풋이삭중은 평균 $1,110 \mathrm{~kg} / 10 \mathrm{a}$ 로 일미찰보다 $10 \%$ 정도 감수하였으나 청주지역에서는 $5 \%$ 증수하 였고 나머지 3 개지역에서는 최소 $4 \%$ 에서 최대 $28 \%$ 까지 감수하 였다(Table 5).

\section{채종시험}

옥수수 교잡종 종자 $\left(\mathrm{F}_{1}\right)$ 를 생산할 때 채종지의 기상, 토양 등 환경조건에 따라 모본과 부본의 개화 반응에 차이가 나타날 수 있다. 2014년 옥수수 종자 생산이 주로 이루어지는 영월 지역에 황미찰 모본(KY30)과 부본(KY9)을 재식비율 2:1, 3:1로

Table 3. Resistance to disease, corn borer and lodging of Hwangmichal in regional yield test (2012 2014).

\begin{tabular}{|c|c|c|c|c|}
\hline \multirow{2}{*}{ Hybrid } & \multicolumn{2}{|c|}{ Disease resistance $(0 \sim 9)^{z}$} & \multirow{2}{*}{$\begin{array}{c}\text { Corn borer } \\
\quad(0 \sim 9)^{\mathrm{z}}\end{array}$} & \multirow{2}{*}{$\begin{array}{l}\text { Lodging } \\
(1 \sim 9)^{\mathrm{z}}\end{array}$} \\
\hline & Bipolaris maydis & Exserohilum turcicum & & \\
\hline Hwangmichal & 2 & 1 & 4 & 1 \\
\hline Ilmichal & 3 & 1 & 4 & 2 \\
\hline
\end{tabular}

${ }^{\mathrm{z}}$ Resistance to disease, corn borer and lodging (0, 1: Resistance, 9: Susceptible)

Table 4. The yield of Hwangmichal in number of fresh ears in regional yield test (2012 2014).

\begin{tabular}{|c|c|c|c|c|c|c|c|c|c|c|}
\hline \multirow{2}{*}{ Location } & \multicolumn{5}{|c|}{ Hwangmichal (ears/10a) } & \multicolumn{5}{|c|}{ Ilmichal (ears/10a) } \\
\hline & 12 & 13 & '14 & Mean & Index & 12 & 13 & '14 & Mean & Index \\
\hline Suwon & 6,111 & 6,389 & 6,667 & 6,389 & 112 & 5,556 & 5,278 & 6,250 & 5,694 & 100 \\
\hline Hongcheon & 6,600 & - & 5,693 & 6,146 & 93 & 6,600 & - & 6,600 & 6,600 & 100 \\
\hline Cheongwon & 5,584 & 6,569 & 6,719 & 6,290 & 104 & 5,417 & 6,177 & 6,510 & 6,035 & 100 \\
\hline Daegu & 5,572 & 6,406 & 6,771 & 6,250 & 107 & 5,312 & 5,729 & 6,510 & 5,850 & 100 \\
\hline Jinju & 6,167 & 6,584 & 6,634 & 6,461 & 99 & 6,667 & 6,667 & 6,150 & 6,495 & 100 \\
\hline Mean $^{z}$ & 6,007 & 6,487 & 6,496 & 6,319 & 104 & 5,910 & 5,963 & 6,404 & 6,102 & 100 \\
\hline & & & & & $2.00^{*}$ & & & & & \\
\hline
\end{tabular}

${ }^{\mathrm{z}}$ Student's T-test at the 0.05 probability level $\left({ }^{* *} p<0.01 ;{ }^{*} p<0.05 ;{ }^{\mathrm{ns}} p \geq 0.05\right)$ 
Table 5. The yield of Hwangmichal in fresh ear weight in regional yield test (2012 2014).

\begin{tabular}{|c|c|c|c|c|c|c|c|c|c|c|}
\hline \multirow{2}{*}{ Location } & \multicolumn{5}{|c|}{ Hwangmichal $(\mathrm{kg} / 10 \mathrm{a})$} & \multicolumn{5}{|c|}{ Ilmichal (kg/10a) } \\
\hline & '12 & '13 & '14 & Mean & Index & '12 & '13 & '14 & Mean & Index \\
\hline Suwon & 913 & 833 & 1,153 & 966 & 92 & 957 & 921 & 1,275 & 1,051 & 100 \\
\hline Hongcheon & 1,075 & - & 868 & 971 & 72 & 1,425 & - & 1,275 & 1,350 & 100 \\
\hline Cheongju & 1,140 & 1,231 & 1,228 & 1,200 & 105 & 1,102 & 1,289 & 1,052 & 1,147 & 100 \\
\hline Daegu & 1,062 & 1,206 & 1,369 & 1,213 & 96 & 1,070 & 1,218 & 1,518 & 1,269 & 100 \\
\hline Jinju & 977 & 1,184 & 1,304 & 1,155 & 85 & 1,336 & 1,480 & 1,273 & 1,363 & 100 \\
\hline Mean & 1,033 & 1,114 & 1,184 & 1,110 & 90 & 1,178 & 1,227 & 1,279 & 1,228 & 100 \\
\hline
\end{tabular}

${ }^{\mathrm{z}}$ Student's T-test at the 0.05 probability level $\left({ }^{* *} p<0.01 ;{ }^{*} p<0.05 ;{ }^{\mathrm{ns}} p \geq 0.05\right)$

Table 6. Seed production trial of Hwangmichal in Yeongwol (2014).

\begin{tabular}{|c|c|c|c|c|c|c|c|}
\hline Planting pattern & Inbred & Planting date & Silking date & $\begin{array}{c}\text { Pollen dispersal } \\
\text { period }\end{array}$ & $\begin{array}{l}\text { Plant height } \\
(\mathrm{cm})\end{array}$ & $\begin{array}{l}\text { Ear height } \\
(\mathrm{cm})\end{array}$ & $\begin{array}{c}\mathrm{F}_{1} \text { seed production } \\
(\mathrm{kg} / 10 \mathrm{a})\end{array}$ \\
\hline \multirow{2}{*}{$3: 1$} & KY30 (우) & Jun 10 & Aug 10 & - & 139 & 44 & 102 \\
\hline & KY9 (令) & Jun 10 & - & Aug 7 to 14 & 131 & 34 & \\
\hline \multirow{2}{*}{$2: 1$} & KY30 (우) & Jun 10 & Aug 10 & - & 143 & 45 & 84 \\
\hline & KY9 (令) & Jun 10 & - & Aug 7 to 14 & 138 & 40 & \\
\hline
\end{tabular}

동시파종하여 종자 생산성을 시험한 결과, 모본의 출사기와 부본 의 화분비산기간은 잘 일치하였고 모본과 부본의 간장에 큰 차이가 없었으며 모·부본 재식비율 3:1로 파종한 것이 재식비율 $2: 1$ 로 파종한 것보다 $10 \mathrm{a}$ 당 $18 \mathrm{~kg} / 10 \mathrm{a}$ 정도 증수하여 황미찰의 종자생산 시 모·부본 재식비율을 $3: 1$ 로 하는 것이 유리할 것으 로 생각되었다(Table 6).

\section{적응지역 및 재배상 유의점}

황미찰은 제주도를 제외한 전국에서 재배가 가능하며 1 대 교잡종 종자를 사용하므로 매년 종자를 갱신하여 재배해야 한다. 황미찰은 찰옥수수 열성인자 $(w x)$ 를 보유하고 있어 일반옥수수, 단옥수수( $s u, s e$ 등), 초당옥수수( $s h, s h 2, b t$ 등) 등 다른 종류의 옥수수 화분으로 교배되면 찰옥수수의 고유한 특성이 사라지므 로 다른 종류의 옥수수와 $200 \mathrm{~m}$ 이상 격리하여 재배하여야 한다. 또한, 이삭색이 흰색, 검정색을 나타내는 찰옥수수와 함께 재배 시 찰옥수수 고유의 특성은 변하지 않더라도 이삭의 색깔이 변해 상품성에 영향을 줄 수 있으므로 다른 색의 찰옥수수와 $200 \mathrm{~m}$ 이상 격리하여 재배하여야 한다. 황미찰은 밀식재배 시 이삭이 작아지고 끝달림이 불량해질 수 있으므로 가급적 표준재 배 $(60 \times 25 \mathrm{~cm})$ 보다 넓게 심기를 권장하며 강풍을 동반한 우기 시 포장의 배수관리에도 신경을 써야 한다. 조명나방에는 감수성
이어서 적기 방제가 필요하고 등숙기 노린재의 피해로 이삭 상품성에 영향을 줄 수 있으므로 적기 방제가 필요하다.

\section{적 요}

황미찰은 2014년 농촌진흥청 국립식량과학원에서 개발한 단 교잡종 찰옥수수로 이삭의 색깔은 노란색이며 자식계통 KY30 을 종자친으로 하고 $\mathrm{KY} 9$ 를 화분친으로 한다. 황미찰의 출사일수 는 일미찰(표준품종)과 유사하였고 이삭길이는 $18.4 \mathrm{~cm}$, 이삭직 경은 $4.3 \mathrm{~cm}$ 로 일미찰보다 작았으며 착립장률은 $89 \%$ 로 일미찰 보다 낮은 수준이었다. 아밀로펙틴함량은 $90.9 \%$ 로 일미찰과 유의한 차이가 없었고 과피두께와 백립중, 립장, 립폭 등 알곡의 특성 또한 일미찰과 유사하였으며 카로티노이드 함량은 $32.2 \mu \mathrm{g} / \mathrm{g}$ 로 일미찰보다 높았다. 황미찰의 내병충성은 일미찰과 유사하였 으며 내도복성은 일미찰보다 우수하였다. 황미찰의 단위면적당 이삭수는 일미찰보다 많았고 이삭중은 낮았으며 채종시험결과 종자친과 화분친간 개화기는 잘 일치하였고 모 - 부본 재식비율 을 3:1에서 가장 높은 채종량을 나타내었다. 


\section{사 사}

본 논문은 농촌진흥청 연구사업(세부과제명: 식용옥수수 우량 계통육성시험, 세부과제번호: PJ012497022018)의 지원 및 제1 저자 이진석의 농학박사학위논문(Lee 2017)을 일부 발췌하여 작성한 것이며 본 품종을 육성하는데 협력하여 주신 농촌진흥청 연구정책국, 강원도 옥수수연구소, 충북농업기술원, 경북농업기 술원, 경남농업기술원 및 내병충성 검정을 담당한 국립식량과학 원 재배환경과 등 관계관님들께 감사드립니다.

\section{REFERENCES}

1. Cazzonelli CI. 2011. Carotenoids in nature: insights from plants and beyond. Functional Plant Biology 38: 833-847.

2. Cha SW, Moon HG, Jung TW, Son BY, Park NK, Kim SK, Ryu YH. 2004a. A waxy corn hybrid with early maturity and high yield, "Sinchalok". Korean J Breed Sci 36: 47-48.

3. Cha SW, Moon HG, Jung TW, Son BY, Park NK, Kim SK, Ryu YH, Min HK, Choi HJ, Ryu IM. 2004b. A waxy corn hybrid with long ear and lodging resistance, "Chalok3". Korean J Breed Sci 36:49-50.

4. Drobotă I., Robu T., Drobotă B. 2011. Researches on tillers appearance on actual corn hybrids (Zea mays L.), in the eastern part of romania. Lucrări ştiinţifice (seria Agronomie) 54: 221-226.

5. Eldahshan OA, Singab ANB. 2013. Carotenoids. Journal of Pharmacognesy and Phytochemistry 2: 225-234.

6. FAOSTAT. 2016. Food and agricultural organization of the united nations. FAOSTAT on-line database. http://www.fa o.org/faostat/en/\#data/QC. Accessed August 29, 2018.

7. Hallauer AR. 2001. Specialty corns second edition.

8. Jung TW, Moon HG, Son BY, Kim SJ, Cha SW, Min HK, Choi HJ, Ryu IM. 2006a. A new waxy corn hybrid cultivar, "Chalok 4" with good eating quality and high yield. Korean J Breed Sci 38: 133-134.

9. Jung TW, Moon HG, Son BY, Kim SJ, Cha SW, Min HK, Choi HJ, Ryu IM. 2006b. A new waxy corn hybrid cultivar, "Ilmichal" with good eating quality and lodging resistance. Korean J Breed Sci 38: 135-136.

10. Jung TW, Song SY, Son BY, Kim JT, Baek SB, Kim CK, Kim SL, Kim SJ, Kim SK, Park KJ, Shin HM, Huh CS.
2009. A black waxy hybrid corn, "Heukjinjuchal" with good eating quality. Korean J Breed Sci 41: 599-602.

11. Lee HB, Choi YP, Cha HJ, Lee MS, Choi HG, Joo JI, Kim MK, Ji HC. 2009. A new yellow waxy corn hybrid with high yield "Daehakchal Gold 1" for edible. Korean J Breed Sci 41: 279-283.

12. Lee IS, Choe BH, Lee WK, Lee HB. 1993. Inheritance of pericarp thickness of waxy maize. Korean J Crop Sci 38: 489-494.

13. Lee JS. 2017. Breeding of a yellow waxy corn hybrid resistant to Bipolaris maydis and analysis of moisture-stress tolerance in maize. Doctoral dissertation, Kyungpook National University, Daegu, Korea.

14. Ong ASH, Tee ES. 1992. Natural sources of carotenoids from plants and oils. Meth Enzymol 213: 142-167.

15. Park KJ, Min HK, Heo NK, Ryu SH, Park JY. 2002a. A new high quality and yielding waxy corn hybrid, 'Mibaekchal'. Korean J Breed Sci 34: 377-378.

16. Park KJ, Park JY, Ryu SH, Goh BD, Seo JS, Min HK, Jung TW, Huh CS, Ryu IM. 2007a. A new waxy corn hybrid cultivar, "Mibaek 2" with good eating quality and lodging resistance. Korean J Breed Sci 39: 108-109.

17. Park KJ, Park JY, Seo YH, Ryu SH, Choi JK, Kim HY. 2016. Anthocyanin-rich purple waxy corn single cross hybrid 'Cheongchunchal'. Korean J Breed Sci 48: 541-546.

18. Park KJ, Ryu SH, Min HK, Seo JS, Park JY, Goh BD, Jang JS, and Kim NS. 2007b. A new black waxy corn hybrid cultivar, 'Miheugchal' with good eating quality and high yield. Korean J Breed Sci 39: 106-107.

19. Pfander H. 1992. Carotenoids: an overview. Meth Enzymol 213: 3-13.

20. Rural Development Administration (RDA). 2012. Agricultural science technology standards for investigation of research. pp. 366-385.

21. Rural Development Administration (RDA). 2013. Guide to agricultural technology 35 - Maize.

22. Seo Y, Park K Ryu S, Park J, Choi J. 2018. A high-yielding white waxy corn single cross hybrid 'Jangsuchal' with long ear. Korean J Breed Sci 50: 150-154.

23. Tanaka Y, Sasaki N, Ohmiya A. 2008. Biosynthesis of plant pigments: anthocyanins, betalains and carotenoids. The Plant Journal 54: 733-749. 